\title{
Amazonian Deforestation: Impact of Global Warming on the Energy Balance and Climate
}

\author{
E. C. MORAES \\ Divisão de Sensoriamento Remoto, São Jose dos Campos, São Paulo, Brazil \\ SERgio H. Franchito And V. BRAhMANANDA RaO \\ Centro de Previsão de Tempo e Estudos Climáticos, Instituto Nacional de Pesquisas Espaciais, \\ São Jose dos Campos, São Paulo, Brazil
}

(Manuscript received 6 December 2011, in final form 14 September 2012)

\begin{abstract}
A coupled biosphere-atmosphere statistical-dynamical model is used to study the relative roles of the impact of the land change caused by tropical deforestation and global warming on energy balance and climate. Three experiments were made: 1) deforestation, 2) deforestation $+2 \times \mathrm{CO}_{2}$, and 3) deforestation $+\mathrm{CO}_{2}$, $\mathrm{CH}_{4}, \mathrm{~N}_{2} \mathrm{O}$, and $\mathrm{O}_{3}$ for 2100. In experiment 1, the climatic impact of the Amazonian deforestation is studied. In experiment 2, the effect of doubling $\mathrm{CO}_{2}$ is included. In experiment 3 , the concentrations of the greenhouse gases (GHGs) correspond to the A1FI scenario from the Intergovernmental Panel on Climate Change Special Report on Emissions Scenarios. The results showed that the percentage of the warming caused by deforestation relative to the warming when the increase in GHG concentrations is included is higher than $60 \%$ in the tropical region. On the other hand, with the increase in GHG concentrations, a reduction in the decrease of evapotranspiration and precipitation in the tropical region occurs when compared with the deforestation case. Because of an increase in the net longwave flux at the surface, there is a reduction in the decrease of the surface net radiation flux when compared with the case of only deforestation. This leads to an increase in the surface temperature. Although the changes are higher at $5^{\circ} \mathrm{S}$, the percentage of them when the increase in GHG concentrations is included together with deforestation relative to the case of only deforestation is higher at $5^{\circ} \mathrm{N}$ (higher than $50 \%$ for the surface temperature and higher than $90 \%$ for the foliage and air foliage temperatures) in both experiments 2 and 3 .
\end{abstract}

\section{Introduction}

In the last three decades there has been much effort to investigate the impact of tropical deforestation on climate. Many experiments have been conducted to simulate the effects of deforestation on regional climate with a wide range of climate models, such as complex general circulation models (GCMs) coupled to sophisticated biosphere schemes (Nobre et al. 1991, 2009; Lean and Rowntree 1997; Gedney and Valdes 2000; Chen et al. 2001; Sampaio et al. 2007; Medvigy et al. 2011; and many others), as well as simple climate models

Corresponding author address: Sergio Henrique Franchito, Instituto Nacional de Pesquisas Espaciais, Centro de Previsao de Tempo e Estudos Climaticos, Av. dos Astronautas, 1758 Sao Jose dos Campos, SP 12227-010, Brazil.

E-mail: sergio.franchito@cptec.inpe.br
(Gutman 1984; Franchito and Rao 1992; Varejão-Silva et al. 1998; Silva et al. 2006). The main results of these studies are a reduction in evapotranspiration and precipitation and an increase in the surface temperature in the tropical region when the forest is replaced by pasture.

The future distribution of the tropical biomes depends on the combination of the effects caused by the degradation of land and climate changes, resulting in a warmer and possibly drier climate, as projected by Intergovernmental Panel on Climate Change (IPCC) estimates. Studies with GCMs indicated that the global warming may affect the biomes distribution over South America, where significant portions of rain forest may be replaced by nonforested areas (Cox et al. 2004; Betts et al. 2004, Scholze et al. 2006; Salazar et al. 2007; Cook and Vizy 2008; Malhi et al. 2009). Recently, numerical experiments using a simple mechanistic climate model 
corroborated the hypothesis that the process of savannization of the tropical forest may be accelerated by global warming (Franchito et al. 2011). On the other hand, the main source of anthropogenic emission of carbon dioxide $\left(\mathrm{CO}_{2}\right)$ caused by land use is tropical deforestation.

Some studies have investigated the relative roles on future climate changes of tropical deforestation and the increase in greenhouse gas concentrations. The results suggested that, globally, the warming caused by greenhouse gas concentrations increases dominates over the impact of land change. However, climate change caused by deforestation may also be important at the regional scale (Maynard and Royer 2004; Feddema et al. 2005; Voldoire 2006; Costa and Foley 2000).

The objective of the present study is to investigate the relative roles of the impact of the land change caused by tropical deforestation and global warming on the regional energy balance and climate. For this purpose, a coupled biosphere-atmosphere statistical-dynamical model (SDM) with a detailed parameterization of the radiative processes is used. This kind of model is essentially mechanistic, being directed toward understanding the dependence of a particular mechanism on the other parameters of the problem. In GCMs, since many mechanisms are included simultaneously, the cause and effect relationship is not always possible to trace. Thus, an SDM is better suited for the present study.

This paper differs from the previous study of Franchito et al. (2011) in the following aspect: Franchito et al. (2011) examined the impact of the increase in $\mathrm{CO}_{2}$ concentration predicted for 2100 on the geobotanic zones distribution. For this purpose, an SDM with a bidirectional interaction between vegetation and climate was used. The parameterization of the biofeedback mechanism was based on simple empirical relations between the geobotanic types and climate conditions defined by Budyko (1974). So, in that model the vegetation was continuously changing with the climate. However, they did not discuss the effect of the land change on climate. In the present paper, the relative roles of the greenhouse gases and the land change on the energy balance and climate are investigated. For this purpose, there is a need for a more sophisticated parameterization of the radiation than in Franchito et al. (2011), which includes the effects of the main greenhouse gases. So, the SDM of Moraes et al. $(2004,2005)$ is used in the present study since it contains detailed solarand thermal-infrared radiation models (Chou and Suarez 1994, 1999). The present model has limitations with respect to dynamical vegetation models because there is not a bidirectional interaction between vegetation and climate. So, the impact of climate on the geobotanic zones distribution cannot be studied. However, this is not the scope of the present work. Since we are interested in the investigation of the interactions between the radiation fluxes and climate, the SDM is adequate for the present study.

In section 2, the biosphere-atmosphere coupled SDM is presented. Section 3 presents the numerical experiments; sections 4 and 5 contain the results and the summary and conclusions, respectively.

\section{The model}

The model used in this study is the SDM of Moraes et al. $(2004,2005)$. This SDM is a later (better) version of the coupled biosphere-atmosphere climate model developed by Varejão-Silva et al. (1998) in which a detailed parameterization of the radiative processes was included (Chou and Suarez 1994, 1999). The model is a two-layer zonally averaged global primitive equation model in sigma coordinates. The energy fluxes such as solar radiation, thermal-infrared radiation, sensible and latent heat fluxes, and subsurface flux are computed separately for the land fraction (soil and vegetation) and the remaining part (covered by ocean-ice-snow) of the latitude belt. Thus, the portions of ocean, ice, and snow are aggregated into a single class. The parameterizations of the biosphere model based on the BiosphereAtmosphere Transfer Scheme (BATS; Zhang 1994) are used for the land fraction of the latitude belt. For the fraction of the earth's surface covered by oceanice-snow, parameterizations similar to those from the biosphere model are used, but only the effects of oceanice-snow are considered. The biosphere model takes into account the distribution of the surface types according to BATS (Fig. 1). The model considers portions of different types of vegetation in a fraction of land in a latitude belt. These portions are held fixed during the model integration. For the land fraction of a latitude belt, parameters like surface albedo, drag coefficient, stem area index, etc. are obtained through the weighted mean of the specific values of the variables given in BATS using as weight the fraction of land occupied by each vegetation type. A similar procedure is adopted to obtain the fractions covered by ocean-ice-snow. The values of the components of surface and atmospheric fluxes for a latitude belt as a whole are obtained through the weighted mean of these values for the fractions of the earth's surface covered by land and by ocean-icesnow, using as weight the portions of land and oceanice-snow in a latitude belt. This method of averaging first the parameters and then using the averaged parameters set to compute the fluxes is somewhat problematic because the system is highly nonlinear with 

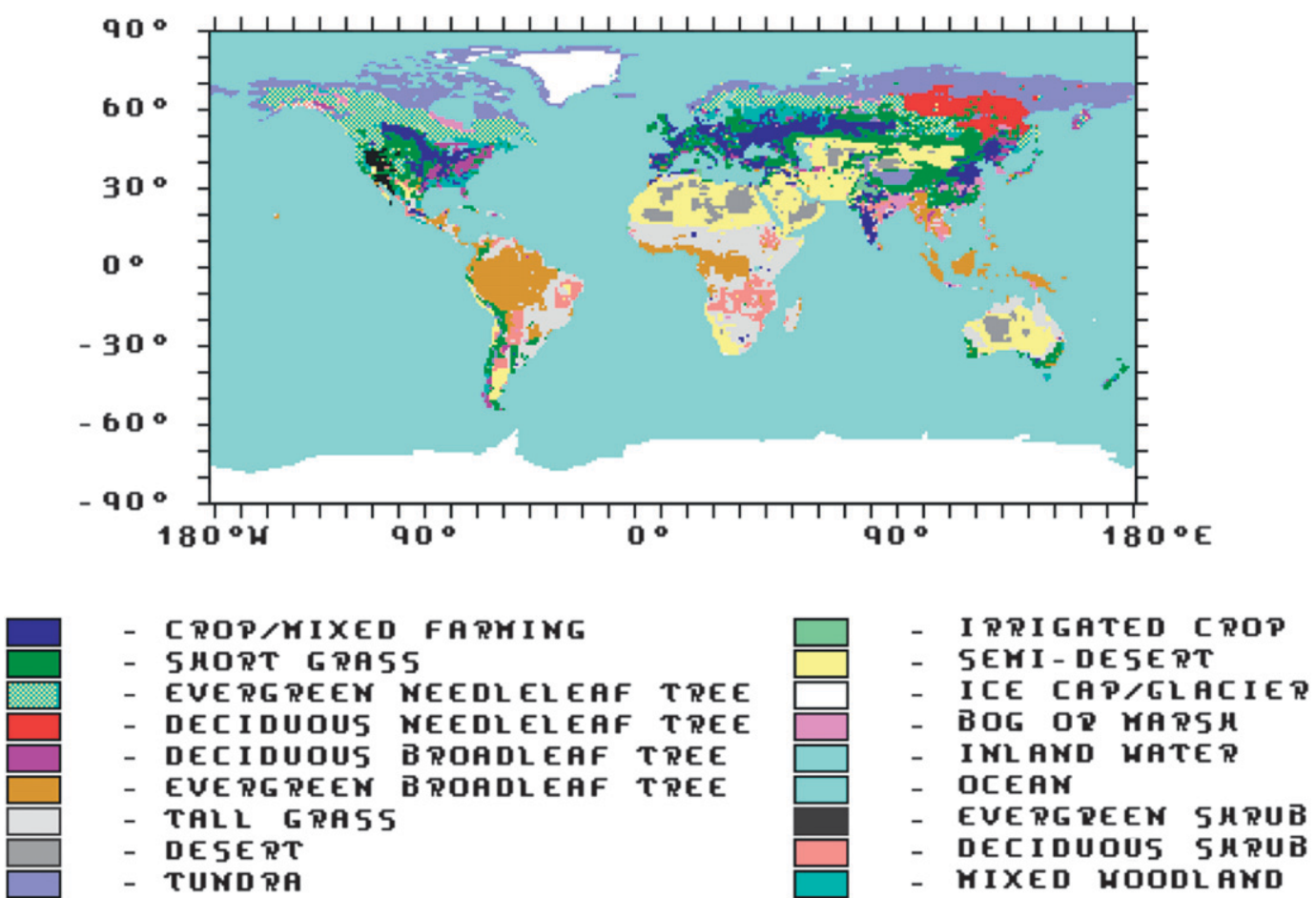

FIG. 1. Distribution of the vegetation types according to the classifications given in BATS. The data, at $1^{\circ} \times 1^{\circ}$, are from Manzi and Planton (1994).

respect to parameter values. A better approach would be to compute the flux for each land cover class and then average the fluxes (Walko et al. 2000). However, taking into account the simplicity of the climate model, the approach used leads to a good simulation of the zonally averaged energy fluxes and climate (Varejão-Silva et al. 1998; Moraes et al. 2004, 2005).

The surface temperatures at the land fraction and the remaining part (ocean-ice-snow) of the latitude belt are calculated at each time step taking into account the energy balance at the surface and the balance of the heat flux and water vapor. In the subsurface heat flux expression, the values of the subsurface temperature (Saltzman and Vernekar 1971) are held fixed in all runs.

The SDM has $10^{\circ}$ latitude resolution and employs a latitudinally centered finite-differencing scheme. An explicit time integration is used with a time step of $30 \mathrm{~min}$. The SDM is run in two steps. First, the original SDM of Varejão-Silva et al. (1998) is integrated without the inclusion of the biosphere parameterization, using as the initial conditions an isothermal atmosphere $(270 \mathrm{~K})$ at rest. The SDM is integrated for a 6-month period forced by mean annual conditions in order to obtain stationary solutions. So, the input variables correspond to mean annual conditions and the solutions correspond to the mean annual zonally averaged climate. Since the values of the $500-\mathrm{hPa}$ temperature and the wind speed are necessary to run the coupled biosphere-atmosphere SDM, they cannot be zero in the initial conditions. So, the mean annual zonally averaged simulation obtained in this step is used as an initial condition for running the coupled biosphere-atmosphere model. In a second step, the SDM is run for a 6-month period including the effects of the biosphere and the new parameterizations of radiation for obtaining new stationary solutions. The new stationary solutions correspond to the simulation of the mean annual zonally averaged climate with the coupled biosphere-atmosphere SDM. Details about the coupled biosphere-atmosphere SDM are given in Varejão-Silva et al. (1998). A detailed description of the inclusion of the radiation models and the validation of the SDM is given by Moraes et al. (2004).

\section{Design of the experiments}

\section{a. Control experiment}

The control experiment considers in each latitude belt the vegetation distribution according to BATS (Fig. 1). The concentration of greenhouse gases is the same as that in Moraes et al. (2004, 2005): $360 \mathrm{ppm}$ for $\mathrm{CO}_{2}, 1760 \mathrm{ppb}$ for methane $\left(\mathrm{CH}_{4}\right)$, and $316 \mathrm{ppb}$ for nitrous oxide $\left(\mathrm{N}_{2} \mathrm{O}\right)$ (Houghton et al. 2001). These 

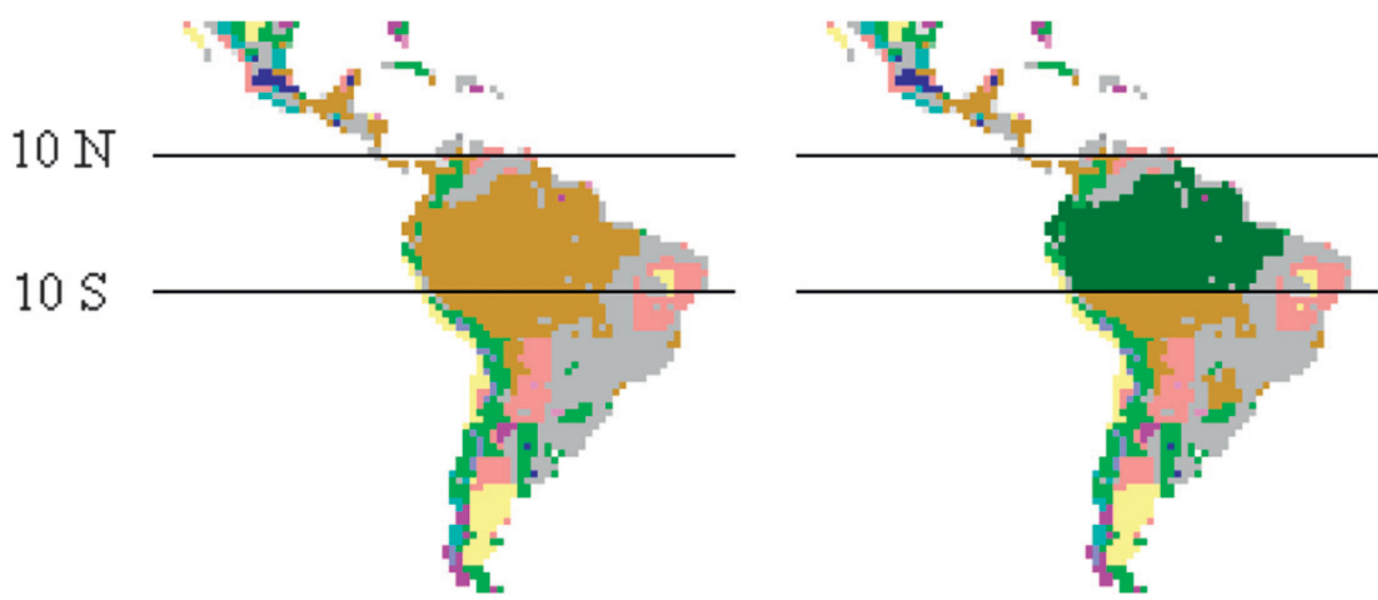

FIG. 2. Amazonian deforestation experiment: (left) control and (right) perturbed cases. The legend colors are the same as in Fig. 1.

values are for the year 2000. The vertical profiles of ozone mixing ratios are obtained from M.-D. Chou (2000, personal communication). They are based on the optical properties of the atmosphere defined by McClatchey et al. (1972) and correspond to the standard atmosphere in tropical, middle, and high latitudes. The cloud amount is provided by the SDM (it is held fixed), and the treatment of clouds for use in the radiation models is described in Moraes et al. (2004). The results of Moraes et al. (2004) showed that the mean annual zonally averaged radiative fluxes and the characteristics of the present climate are well simulated by the SDM (see their Figs. 1 and 3).

\section{b. Impact of deforestation and greenhouse gas concentration increase}

In this section, the three experiments conducted with the SDM are presented: deforestation (experiment 1 ), deforestation and $2 \times \mathrm{CO}_{2}$ (experiment 2 ), and deforestation and the four main greenhouse gas concentrations for 2100 (experiment 3). In experiment 1, the climatic effects of the Amazonian deforestation are simulated, where the evergreen broadleaf tree is replaced by shortgrass in South America from $10^{\circ} \mathrm{S}$ to $10^{\circ} \mathrm{N}$, as shown in Fig. 2. So, all the characteristic parameters of the tropical forest are replaced by those from shortgrass conditions according to BATS. The values of the variables used in the continental area of the latitude belt are obtained through the weighted mean of the specific values using as weight the fraction of each type of vegetation in the latitude belt, but replacing the evergreen broadleaf trees by shortgrass. $\mathrm{CO}_{2}$ has the highest contribution for the increase in mean temperature. Atmospheric $\mathrm{CO}_{2}$ is accelerating upward from decade to decade. For the past $10 \mathrm{yr}$, the average annual rate of increase is $2.07 \mathrm{ppm}$. This rate of increase is more than double the increase in the 1960s (http://co2now.org/). If the mean annual rate of the increase of $\mathrm{CO}_{2}$ concentration is the same $(2.07 \mathrm{ppm})$, the $\mathrm{CO}_{2}$ concentration will be $576 \mathrm{ppm}$ in 2100 . However, only 10 countries are responsible for $2 / 3$ of the emissions. Taking into account the economic increase of the developing countries during the next years, the rate of increase of $\mathrm{CO}_{2}$ concentration will be higher. This corroborates the doubling of $\mathrm{CO}_{2}$ concentration in 2100.Thus, in experiment 2 the climatic effects of the Amazonian deforestation are simulated together with a plausible increase in $\mathrm{CO}_{2}$ concentration in 2100. In experiment 3 , the effect of deforestation is taken into account together with the increase in the concentrations of the four major anthropogenic greenhouse gases predicted for $2100\left[\mathrm{CO}_{2}, \mathrm{CH}_{4}, \mathrm{~N}_{2} \mathrm{O}\right.$, and ozone $\left(\mathrm{O}_{3}\right)$ ]. In experiment 3 , the concentrations of the anthropogenic greenhouse gases are changed from their actual values (values for year 2000) to those from the more drastic IPCC Special Report on Emissions Scenarios (SRES) scenario for 2100 (A1FI-2100). The concentrations of $\mathrm{CO}_{2}, \mathrm{CH}_{4}$, and $\mathrm{N}_{2} \mathrm{O}$ are changed from 360 to $970 \mathrm{ppm}$, from 1760 to $3730 \mathrm{ppb}$, and from 316 to $460 \mathrm{ppb}$, respectively; in the case of the change in the concentration of tropospheric $\mathrm{O}_{3}$, the values given by McClatchey et al. (1972) are increased by $62 \%$.

\section{Results}

Figures $3 a-c$ show the changes in the energy balance in the three experiments. The changes (perturbed minus control) in specific humidity, evaporation, and precipitation are presented in Figs. $4 \mathrm{a}-\mathrm{c}$, while the changes in the surface temperature, foliage temperature, and foliage air layer temperature are shown in Figs. 5a-c. As 

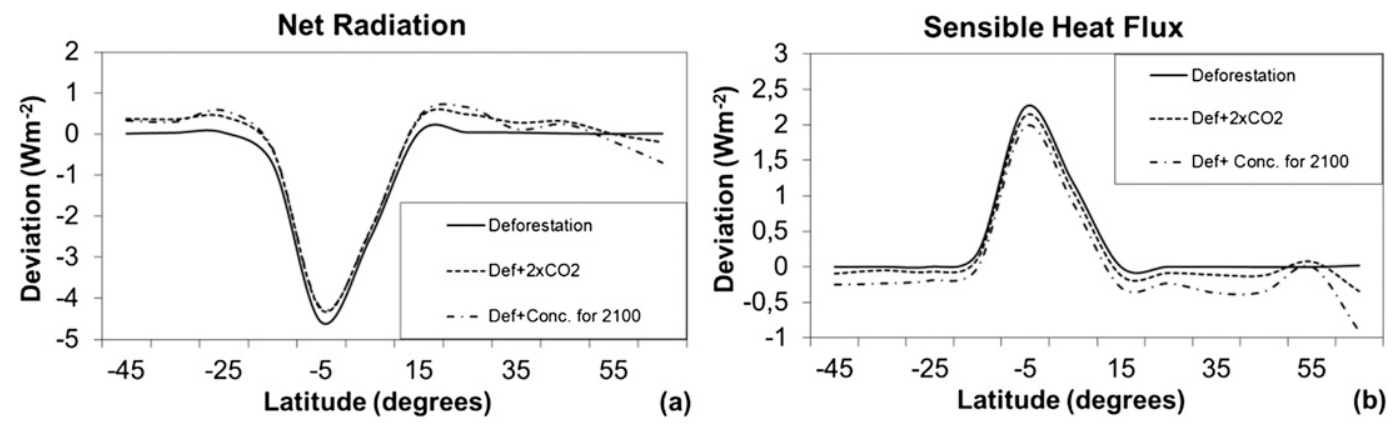

Latent Heat Flux

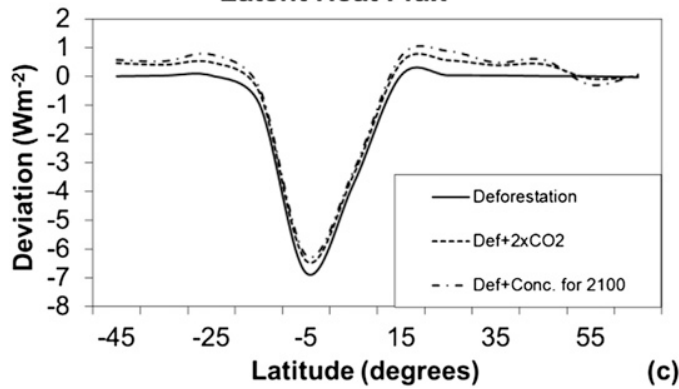

FIG. 3. Changes in the energy balance in the continental region in the three experiments $\left(\mathrm{W} \mathrm{m}^{-2}\right)$ : (a) net surface radiation, (b) surface sensible heat flux, and (c) surface latent heat flux.

can be seen, the greatest changes occur in the tropical region where the evergreen broadleaf trees of Amazonia are replaced by shortgrass. The changes are higher in the tropical Southern Hemisphere since most of the Amazonian forest is concentrated in this region. In experiment 1 (deforestation), the surface net radiation decreases $\left(-4.6 \mathrm{~W} \mathrm{~m}^{-2}\right.$ at $\left.5^{\circ} \mathrm{S}\right)$ because of the higher surface land albedo. At the foliage air layer, the specific humidity decreases $\left(-0.85 \mathrm{~g} \mathrm{~kg}^{-1}\right.$ at $\left.5^{\circ} \mathrm{S}\right)$ in the deforestation case compared with the control case. Consequently, the latent heat flux from the surface is lower $\left(-6.9 \mathrm{~W} \mathrm{~m}^{-2}\right.$ at $\left.5^{\circ} \mathrm{S}\right)$. The reduction in the latent heat released by the surface leads to a decrease in the evapotranspiration $\left(-8.5 \mathrm{~cm} \mathrm{yr}^{-1}\right.$ at $\left.5^{\circ} \mathrm{S}\right)$ in the deforested area. The evapotranspiration decreases in the perturbed region are mainly due to the decrease in the net surface radiation. This occurs because of the higher solar radiation spectral reflectance of the shortgrass compared with that of the evergreen broadleaf tree. Consequently, there is a decrease in the precipitation $\left(-8.21 \mathrm{~cm} \mathrm{yr}^{-1}\right.$ at $\left.5^{\circ} \mathrm{S}\right)$ in the deforestation case relative to the control experiment. Because of the reduction in evapotranspiration, the surface temperature is higher $\left(+1.31^{\circ} \mathrm{C}\right.$ at $\left.5^{\circ} \mathrm{S}\right)$ in the deforestation experiment relative to the control experiment. This warming occurs in the foliage air layer, so that there is an increase in the foliage temperature $\left(+0.73^{\circ} \mathrm{C}\right.$ at $\left.5^{\circ} \mathrm{S}\right)$ and in the foliage air layer temperature $\left(+0.74^{\circ} \mathrm{C}\right.$ at $\left.5^{\circ} \mathrm{S}\right)$. Since the foliage air layer temperature is higher, there is an increase in the sensible heat flux from surface to the atmosphere $\left(+2.3 \mathrm{~W} \mathrm{~m}^{-2}\right.$ at $\left.5^{\circ} \mathrm{S}\right)$, which partly compensates for the decrease in the latent heat flux in the deforestation case relative to the control case. Thus, in the deforestation experiment the effect of the reduction in evapotranspiration overcomes the effect of the decrease in the net surface radiation, so that an increase in the temperature occurs. The changes discussed above are presented in Tables 1-3.

The changes obtained with the SDM are, in general, in agreement with those from GCMs coupled to sophisticated biosphere schemes (Nobre et al. 1991; Sud et al. 1990; Lean and Rowntree 1997; Sampaio et al. 2007; Lawrence et al. 2007; Nobre et al. 2009; Medvigy et al. 2011, and many others), although they are lower. This will be commented on at the end of this section.

The effect of the regional changes in $\mathrm{CO}_{2}$ and in the anthropogenic greenhouse gases predicted for 2100 together with that caused by tropical deforestation are also show in Figs. 3-5 and Tables 1-3. It can be seen that the higher impact on the energy balance is caused by the degradation of land (Fig. 3). When the increase in greenhouse gases is taken into account together with the effect of deforestation, the changes are reduced, except in the case of the temperature. This is because of the increase in the thermal-infrared radiation flux emitted by the atmosphere toward the surface. The inclusion of the greenhouse gases leads to a reduction in the decrease of the specific humidity or even an increase in the 

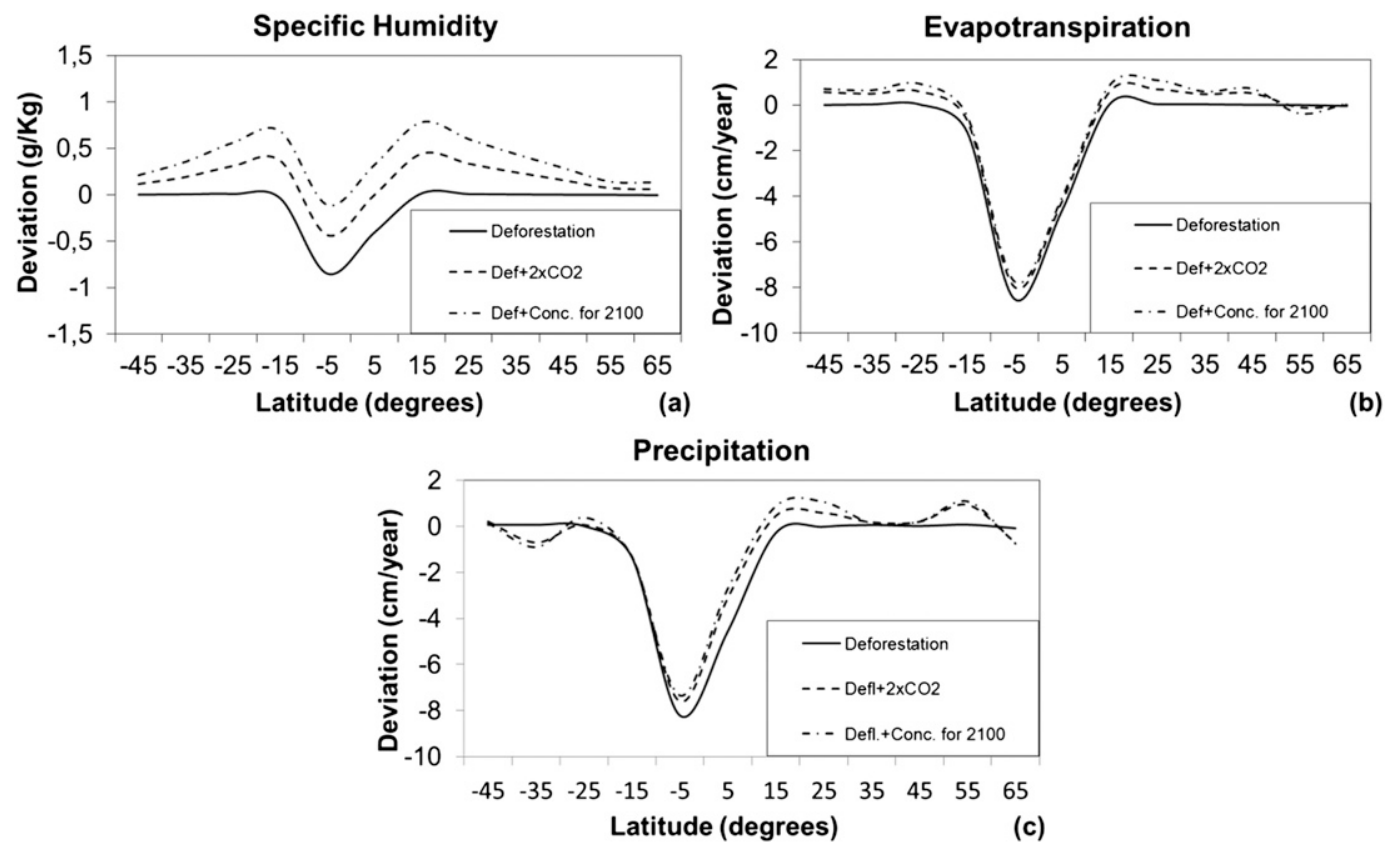

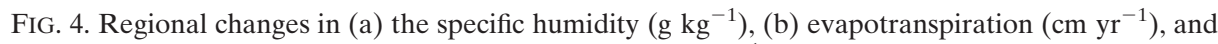
(c) precipitation $\left(\mathrm{cm} \mathrm{yr}^{-1}\right)$.

specific humidity (Fig. 4a). The higher effect occurs with the increase of concentrations of the four main greenhouse gases for 2100. As shown in Table 1, deforestation leads to decreases in the specific humidity of -0.85 and $-0.41 \mathrm{~g} \mathrm{~kg}^{-1}$ at $5^{\circ} \mathrm{S}$ and $5^{\circ} \mathrm{N}$, respectively. The increase of the four main greenhouse gas concentrations predicted for 2100 leads to a decrease of $-0.11 \mathrm{~g} \mathrm{~kg}^{-1}$ $(+87.1 \%)$ and an increase of $+0.32 \mathrm{~g} \mathrm{~kg}^{-1}(+178.1 \%)$ at $5^{\circ} \mathrm{S}$ and $5^{\circ} \mathrm{N}$, respectively. Thus, when the greenhouse gas concentrations are increased in the deforested area,
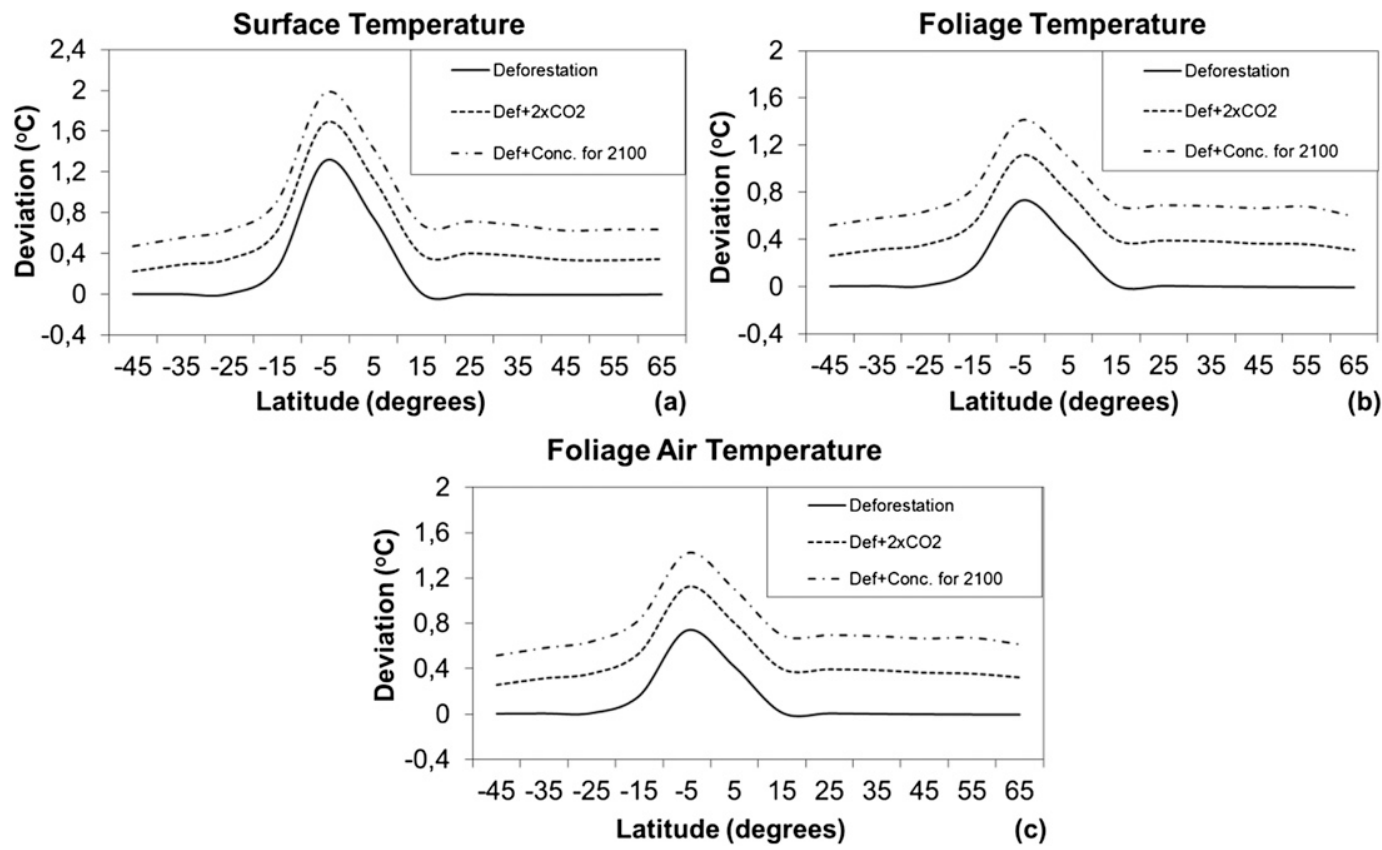

FIG. 5. Regional changes in (a) surface temperature $\left({ }^{\circ} \mathrm{C}\right)$, (b) foliage temperature $\left({ }^{\circ} \mathrm{C}\right)$, and (c) foliage air temperature $\left({ }^{\circ} \mathrm{C}\right)$. 
TABLE 1. Changes in the specific humidity for the deforestation experiment and the percentage relative to the experiments with $2 \times \mathrm{CO}_{2}$ and the four major greenhouse gases $\left(\mathrm{CO}_{2}, \mathrm{CH}_{4}, \mathrm{~N}_{2} \mathrm{O}\right.$, and $\mathrm{O}_{3}$ ) for 2100

\begin{tabular}{llc}
\hline \multicolumn{1}{c}{ Expt } & $5^{\circ} \mathrm{S}\left(\mathrm{g} \mathrm{kg}^{-1}\right)$ & $5^{\circ} \mathrm{N}\left(\mathrm{g} \mathrm{kg}^{-1}\right)$ \\
\hline Deforestation & -0.85 & -0.41 \\
Deforestation together & $-0.43(+49.4 \%)$ & $0(+100 \%)$ \\
$\quad$ with $2 \times \mathrm{CO}_{2}$ & & \\
Deforestation together & $-0.11(+87.1 \%)$ & $+0.32(+178.1 \%)$ \\
$\quad$ with $\mathrm{CO}_{2}, \mathrm{CH}_{4}, \mathrm{~N}_{2} \mathrm{O}$, & & \\
and $\mathrm{O}_{3}$ concentrations & & \\
predicted for 2100 & \\
\hline
\end{tabular}

there is an increase or a reduction in the decrease of the specific humidity relative to the case when only deforestation was included (Fig. 4a). The changes in the evapotranspiration and precipitation in the three experiments are shown in Figs. $4 \mathrm{~b}$ and $4 \mathrm{c}$, respectively. Because of the changes in the net surface radiation (Fig. $3 a)$, there is a reduction in the decrease of evapotranspiration (and consequently in precipitation) when the concentrations of the anthropogenic gases are increased in the deforested area. Again, the greatest changes occur in the case of an increase in $\mathrm{CO}_{2}, \mathrm{CH}_{4}, \mathrm{~N}_{2} \mathrm{O}$, and $\mathrm{O}_{3}$ predicted for 2100 together with deforestation. As shown in Table 2, the decreases in the evapotranspiration change from -8.5 and $-4.63 \mathrm{~cm} \mathrm{yr}^{-1}$ at $5^{\circ} \mathrm{S}$ and $5^{\circ} \mathrm{N}$, respectively, to $-7.74 \mathrm{~cm} \mathrm{yr}^{-1}(+8.9 \%)$ and $-4.07 \mathrm{~cm} \mathrm{yr}^{-1}(+12.1 \%)$ when the concentrations of the four main greenhouse gases for 2100 are included in the deforested area, while the decreases in precipitation change from -8.21 and $-4.55 \mathrm{~cm} \mathrm{yr}^{-1}$ at $5^{\circ} \mathrm{S}$ and $5^{\circ} \mathrm{N}$, respectively, to $-7.33 \mathrm{~cm} \mathrm{yr}^{-1}(+10.7 \%)$ and $-2.70 \mathrm{~cm} \mathrm{yr}^{-1}(+40.7 \%)$. These findings are in agreement with the results of Costa and Foley (2000) although the changes are lower in the present study.

As mentioned earlier, because of the reduction in the evapotranspiration the surface temperature, the foliage temperature, and the foliage air temperature are increased when the evergreen broadleaf tree is replaced by shortgrass in the Amazonian region. In the case with an increase in the concentrations of greenhouse gases, the evapotranspiration does not decrease as much relative to the case without the inclusion of the change in greenhouse gas concentrations. But instead of a corresponding reduction in the increase of the temperatures, the temperatures come out higher in the case with greenhouse gases. In the case with greenhouse gases, the reduction in the net surface radiation is lower not because of the albedo (as in the case of deforestation), but because there is an additional effect of the increase of thermal-infrared radiation flux emitted by the atmosphere toward the surface. As shown in Table 3 and Figs. $5 a-c$, the changes in the surface temperature are higher in the case of deforestation together with the increase in the four main greenhouse gas concentrations predicted for $2100\left(1.98^{\circ} \mathrm{C}\right)$. Taking into account that the increase in the surface temperature is $1.31^{\circ} \mathrm{C}$ in the deforestation experiment, the percentage of the warming caused by deforestation relative to the warming when the increase of the four main greenhouse gas concentrations predicted for 2100 is included together is higher than $60 \%$ in the tropical region. This is in agreement with previous studies (Maynard and Royer 2004; Feddema et al. 2005; Voldoire 2006), which suggests that the warming caused by deforestation may be important on a regional scale. Although the changes (perturbed minus control) are higher at $5^{\circ} \mathrm{S}$, the percentage of the changes in the experiments when the increase of greenhouse gas concentrations is included together with deforestation relative to the deforestation experiment is higher at $5^{\circ} \mathrm{N}$ (higher than $50 \%$ for the surface temperature and higher than $90 \%$ for the foliage and air foliage temperatures).

Figure 5 and Table 3 show the changes in the surface temperature, the foliage temperature, and the foliage air temperature for experiments 1-3. As shown in Table 3, at $5^{\circ} \mathrm{N}$ the percentages of the changes in the surface temperature, foliage temperature, and foliage air temperature in experiment 2 (deforestation $+2 \times \mathrm{CO}_{2}$ ) relative to the deforested case are $50.7 \%, 90.5 \%$, and $90.5 \%$, respectively. When the concentrations of the four major

TABLE 2. Changes in the evapotranspiration and precipitation for the deforestation experiment and the percentage relative to the experiments with $2 \times \mathrm{CO}_{2}, 4 \times \mathrm{CO}_{2}$, and the four major greenhouse gases $\left(\mathrm{CO}_{2}, \mathrm{CH}_{4}, \mathrm{~N}_{2} \mathrm{O}\right.$, and $\left.\mathrm{O}_{3}\right)$ for 2100 .

\begin{tabular}{|c|c|c|c|c|}
\hline \multirow[b]{2}{*}{ Expt } & \multicolumn{2}{|c|}{ Evapotranspiration $\left(\mathrm{cm} \mathrm{yr}^{-1}\right)$} & \multicolumn{2}{|c|}{ Precipitation $\left(\mathrm{cm} \mathrm{yr}^{-1}\right)$} \\
\hline & $5^{\circ} \mathrm{S}$ & $5^{\circ} \mathrm{N}$ & $5^{\circ} \mathrm{S}$ & $5^{\circ} \mathrm{N}$ \\
\hline Deforestation & -8.5 & -4.63 & -8.21 & -4.55 \\
\hline Deforestation together with $2 \times \mathrm{CO}_{2}$ & $\begin{array}{l}-7.98 \\
(+6.1 \%)\end{array}$ & $\begin{array}{c}-4.24 \\
(+8.4 \%)\end{array}$ & $\begin{array}{l}-7.59 \\
(+7.6 \%)\end{array}$ & $\begin{array}{c}-3.1 \\
(+31.9 \%)\end{array}$ \\
\hline $\begin{array}{l}\text { Deforestation together with } \mathrm{CO}_{2}, \mathrm{CH}_{4}, \mathrm{~N}_{2} \mathrm{O} \text {, and } \mathrm{O}_{3} \\
\text { concentrations predicted for } 2100\end{array}$ & $\begin{array}{c}-7.74 \\
(+8.9 \%)\end{array}$ & $\begin{array}{c}-4.07 \\
(+12.1 \%)\end{array}$ & $\begin{array}{c}-7.33 \\
(+10.7 \%)\end{array}$ & $\begin{array}{c}-2.70 \\
(+40.7 \%)\end{array}$ \\
\hline
\end{tabular}


TABLE 3. Changes in the surface temperature $T_{s}$, foliage temperature $T_{f}$, and foliage air temperature $T_{\text {af }}$ for the deforestation experiment and the percentage relative to the experiments with $2 \times \mathrm{CO}_{2}$ and the four major greenhouse gases $\left(\mathrm{CO}_{2}, \mathrm{CH}_{4}, \mathrm{~N}_{2} \mathrm{O}\right.$, and $\left.\mathrm{O}_{3}\right)$ for 2100 .

\begin{tabular}{lllll}
\hline \hline \multicolumn{1}{c}{ Expt } & Lat & \multicolumn{1}{c}{$T_{s}\left({ }^{\circ} \mathrm{C}\right)$} & \multicolumn{1}{c}{$T_{f}\left({ }^{\circ} \mathrm{C}\right)$} & $T_{\text {af }}\left({ }^{\circ} \mathrm{C}\right)$ \\
\hline Deforestation & $5^{\circ} \mathrm{S}$ & 1.31 & 0.73 & 0.74 \\
& $5^{\circ} \mathrm{N}$ & 0.75 & 0.42 & 0.42 \\
Deforestation together with $2 \times \mathrm{CO}_{2}$ & $5^{\circ} \mathrm{S}$ & $1.68(+28.2 \%)$ & $1.11(+52 \%)$ & $1.13(+52.7 \%)$ \\
& $5^{\circ} \mathrm{N}$ & $1.13(+50.7 \%)$ & $0.8(+90.5 \%)$ & $0.8(+90.5 \%)$ \\
Deforestation together with $\mathrm{CO}_{2}, \mathrm{CH}_{4}, \mathrm{~N}_{2} \mathrm{O}$, and $\mathrm{O}_{3}$ & $5^{\circ} \mathrm{S}$ & $1.98(+51.1 \%)$ & $1.41(+93.2 \%)$ & $1.42(+91.9 \%)$ \\
concentrations predicted for 2100 & $5^{\circ} \mathrm{N}$ & $1.43(+90.7 \%)$ & $1.1(+162 \%)$ & $1.1(+162 \%)$ \\
\hline
\end{tabular}

greenhouse gases predicted for 2100 are included together with deforestation (experiment 3), these changes are $90.7 \%, 162 \%$, and $162 \%$, respectively.

The results shown above indicate that the changes are bigger in experiment 3 than in experiment 2 . Besides the inclusion of the other three major greenhouse gases, the concentration of $\mathrm{CO}_{2}$ in experiment 3 is higher than in experiment 2. Experiment 3 corresponds to the simulation of future climate using the most drastic greenhouse scenario (A1FI) together with deforestation, whereas in experiment 2 the climate effects correspond to a plausible $\mathrm{CO}_{2}$ scenario for 2100 together with deforestation. Although the changes are lower in experiment 2, they are in agreement with those in experiment 3 , reinforcing the necessity of the mitigation of climate change associated with global warming.

When compared with the IPCC Fourth Assessment Report (AR4) model estimates, the changes in the surface temperature in the SDM are lower. As commented upon by Franchito et al. (2011), the response of the atmosphere in the SDM is smoothed out in comparison with in the GCMs. In the case of three-dimensional GCMs including the diurnal cycle, the changes are computed in small regional areas, so that a local atmospheric response can be much pronounced. In addition, there are differences in the structures of the models, such as the resolutions and parameterizations incorporated. However, the changes in the SDMs are in qualitatively good agreement and are in the same direction when compared with the GCMs, indicating that the physics of the problem is included. SDMs are essentially mechanistic so that they are uniquely suitable for understanding the feedbacks acting within the climate system, and changes of the same order as those in GCMs are not expected. Because of their simplicity, SDMs are useful when studying cause and effect relationships and are good complements to GCMs.

\section{Summary and conclusions}

In this paper, the relative roles of the impact of the land change caused by tropical deforestation and global warming on energy balance and climate were investigated. For this purpose, a coupled biosphereatmosphere SDM with a detailed parameterization of solar radiation and thermal-infrared radiation fluxes was used. This kind of model is directed toward understanding the dependence of a particular mechanism on the other parameters of the problem. The simulation of the mean annual zonally averaged climate was taken as the control experiment. In the control experiment the concentrations of greenhouse gases were for the year 2000. Three experiments were made: 1) deforestation, 2) deforestation together with $2 \times \mathrm{CO}_{2}$, and 3) deforestation together with the concentrations of the four main greenhouse gases predicted for 2100: $\mathrm{CO}_{2}, \mathrm{CH}_{4}$, $\mathrm{N}_{2} \mathrm{O}$, and $\mathrm{O}_{3}$. In the deforestation experiment, the climatic impact of the Amazonian deforestation, where the evergreen broadleaf trees are substituted by shortgrasses in South America from $10^{\circ} \mathrm{S}$ to $10^{\circ} \mathrm{N}$, was studied. In experiment 2 , the doubling of the $\mathrm{CO}_{2}$ concentration was considered together with deforestation. In experiment 3 , the concentrations of the greenhouse gases corresponding to the A1FI scenario together with deforestation were examined.

In the deforestation experiment relative to the control experiment, the changes in the continental portion of the latitude belt showed a decrease in the surface net radiation, the specific humidity in the foliage air layer, the latent heat flux, evapotranspiration, and precipitation, as well as an increase in the sensible heat flux, which compensates partially for the reduction in the latent heat flux in the perturbed region. The changes were greater in the latitude belt centered at $5^{\circ} \mathrm{S}$, where most of the Amazonian forest is concentrated. Also, there was an increase in the surface temperature and in the foliage and foliage air temperatures. This indicates that the effect of the reduction in the evapotranspiration dominated the increase of the surface albedo when the tropical forest was replaced by shortgrass. These results were in agreement with those obtained from complex GCMs.

When the increase in greenhouse gas concentrations was taken into account together with the effect of deforestation, the changes in the energy fluxes were reduced. This was caused by the increase in the thermal-infrared 
radiation flux emitted by the atmosphere toward the surface. As a consequence of the changes in the net surface radiation, there was a reduction in the decrease of evapotranspiration and in precipitation when the concentrations of the anthropogenic gases increased in the deforested area. For example, the decreases in evapotranspiration and precipitation at $5^{\circ} \mathrm{S}$ were reduced from -8.5 and $-8.21 \mathrm{~cm} \mathrm{yr}^{-1}$ in the deforested case to -7.74 and $-7.33 \mathrm{~cm} \mathrm{yr}^{-1}$, respectively, when the concentrations of $\mathrm{CO}_{2}, \mathrm{CH}_{4}, \mathrm{~N}_{2} \mathrm{O}$, and $\mathrm{O}_{3}$ predicted for 2100 were included together. Although the evapotranspiration did not decrease as much when compared with the case without greenhouse gases, the temperatures were higher. This was because the reduction in the net surface radiation was lower not because of the albedo (as in the case of deforestation), but because there was an additional effect of the increase of the thermalinfrared radiation flux emitted by the atmosphere toward the surface. The changes (perturbed minus control) were higher in the surface temperature (the change in the surface temperature increased from $1.31^{\circ} \mathrm{C}$ at $5^{\circ} \mathrm{S}$ in the deforestation to $1.98^{\circ} \mathrm{C}$ when the four main anthropogenic gases were included together). The percentage of the warming caused by deforestation in the tropical region relative to the warming when the increase of the four main greenhouse gas concentrations was included together was higher than $60 \%$, suggesting that the warming caused by deforestation may be more important on a regional scale than the greenhouse gas effect. Although the changes (perturbed minus control) were higher in the latitude belt centered at $5^{\circ} \mathrm{S}$, the percentage of the changes in the experiments when the increase in greenhouse gas concentrations was included together with deforestation relative to the deforestation experiment were higher in the latitude belt centered at $5^{\circ} \mathrm{N}$ (higher than $50 \%$ for the surface temperature and higher than $90 \%$ for the foliage and air foliage temperatures).

Although the changes were lower when considering a plausible $\mathrm{CO}_{2}$ scenario for 2100 (experiment 2), they were in agreement with those using the highest greenhouse gas scenario-A1FI (experiment 3) - reinforcing the necessity of the mitigation of climate change associated with global warming.

Acknowledgments. The authors are thankful to Dr. Ming-Dah Chou, chair research professor, National Taiwan University, for providing the radiation models code.

\section{REFERENCES}

Betts, R. A., P. M. Cox, M. Collins, P. P. Harris, C. Huntingford, and C. D. Jones, 2004: The role of ecosystem-atmosphere interactions in simulated Amazonian precipitation decrease and forest dieback under global climate warming. Theor. Appl. Climatol., 78, 157-175.

Budyko, M. I., 1974: Climate and Life. Academic Press, 508 pp.

Chen, T.-C., J.-H. Yoon, K. J. St. Croix, and E. S. Takle, 2001: Suppressing impacts of the Amazonian deforestation by global circulation change. Bull. Amer. Meteor. Soc., 82, 2209-2216.

Chou, M.-D., and M. J. Suarez, 1994: An efficient thermal infrared radiation parameterization for use in general circulation models. NASA Tech. Memo. 104606, Tech. Rep. Series on Global Modeling and Data Assimilation, Goddard Space Flight Center, Greenbelt, MD, 102 pp.

_, and — 1999: A solar radiation parameterization for atmospheric studies. NASA Tech. Memo. NASA/TM-1999104606, Vol. 15, Tech. Rep. Series on Global Modeling and Data Assimilation, Goddard Space Flight Center, Greenbelt, MD, $38 \mathrm{pp}$.

Cook, K. H., and K. H. Vizy, 2008: Effects of twenty-first-century climate change on the Amazon rain forest. J. Climate, 21, 542560.

Costa, M. H., and J. A. Foley, 2000: Combined effects of deforestation and doubled atmospheric $\mathrm{CO}_{2}$ concentration on climate of Amazonia. J. Climate, 13, 18-34.

Cox, P. M., R. A. Betts, M. Collins, P. P. Harris, C. Huntingford, and C. D. Jones, 2004: Amazonian forest dieback under climatecarbon cycle projections for the 21st century. Theor. Appl. Climatol., 78, 137-156, doi:10.1007/s00704-004-0049-4.

Feddema, J. J., K. W. Oleson, G. B. Bonan, L. O. Mearns, L. E. Buja, G. A. Meehl, and W. M. Washington, 2005: The importance of land-cover change in simulating future climates. Science, 310, 1674-1678.

Franchito, S. H., and V. B. Rao, 1992: Climatic change due to land surface alterations. Climatic Change, 22, 1-34.

,-- , and E. C. Moraes, 2011: Impact of global warming on the geobotanic zones: An experiment with a statisticaldynamical climate model. Climate Dyn., 37, 2011-2034.

Gedney, N., and P. J. Valdes, 2000: The effect of Amazonian deforestation on the Northern Hemisphere circulation and climate. Geophys. Res. Lett., 27, 3053-3056.

Gutman, G., 1984: Numerical experiments on land surface alterations with a zonal model allowing for interaction between the geobotanic state and climate. J. Atmos. Sci., 41, 26792685.

Houghton, J. T., and Coauthors, 2001: Climate Change 2001: The Scientific Basis. Cambridge University Press, 881 pp.

Lawrence, D. M., P. E. Thornton, K. W. Oleson, and G. B. Bonan, 2007: The partitioning of evapotranspiration into transpiration, soil evaporation, and canopy evaporation in a GCM: Impacts on land-atmosphere interaction. J. Hydrometeor., 8, 862-880.

Lean, J., and P. R. Rowntree, 1997: Understanding the sensitivity of a GCM simulation of Amazonian deforestation to the specification of vegetation and soil characteristics. J. Climate, 10, 1216-1235.

Malhi, Y., and Coauthors, 2009: Exploring likelihood and mechanism of a climate-change-induced dieback of the Amazon rainforest. Proc. Natl. Acad. Sci. USA, 106, 20 610-20 615.

Manzi, A. O., and S. Planton, 1994: Implementation of ISBA parameterization scheme for land surface processes in a GCMAn annual cycle experiment. J. Hydrol., 155, 353-387.

Maynard, K., and J.-F. Royer, 2004: Effects of "realistic" landcover change on a greenhouse-warmed African climate. Climate Dyn., 22, 343-358. 
McClatchey, R. A., R. W. Fenn, J. E. A. Selby, F. E. Voltz, and J. S. Garing, 1972: Optical properties of the atmosphere. Air Force Cambridge Research Laboratory Tech. Rep. AFCRL-720497, Bedford, MA, 108 pp.

Medvigy, D., R. L. Walko, and R. Avissar, 2011: Effects of deforestation on spatiotemporal precipitation in South America. J. Climate, 24, 2147-2163.

Moraes, E. C., S. H. Franchito, and V. B. Rao, 2004: Effects of biomass burning in Amazonia on climate: A numerical experiment with a statistical-dynamical model. J. Geophys. Res., 109, D05109, doi:10.1029/2003JD003800.

,$- \ldots$, and — 2005: Evaluation of surface air temperature change due to the greenhouse gases increase with a statisticaldynamical model. J. Geophys. Res., 110, D24109, doi:10.1029/ 2004JD005679.

Nobre, C. A., P. J. Sellers, and J. Shukla, 1991: Amazonian deforestation and regional climate change. J. Climate, 4, 957988.

Nobre, P., M. Malagutti, D. F. Urbano, R. A. F. Almeida, and E. Giarolla, 2009: Amazon deforestation and climate change in a coupled model simulation. J. Climate, 22, 5686-5697.

Salazar, R. F., C. A. Nobre, and M. D. Oyama, 2007: Climate change consequences on the biome distribution in tropical South America. Geophys. Res. Lett., 34, L09708, doi:10.1029/ 2007GL029695.

Saltzman, B., and A. D. Vernekar, 1971: An equilibrium solution for the axially-symmetric components of the Earth's macroclimate. J. Geophys. Res., 76, 1498-1524.
Sampaio, G., C. Nobre, M. H. Costa, P. Satyamurty, and B. S. Soares-Filho, 2007: Regional climate change over eastern Amazonia caused by pasture and soybean cropland expansion. Geophys. Res. Lett., 34, L17709, doi:10.1029/2007GL030612.

Scholze, M., W. Knorr, N. W. Arnell, and I. C. Prentice, 2006: A climate change risk analysis for world ecosystems. Proc. Natl. Acad. Sci. USA, 103, 13 116-13 120.

Silva, M. E. S., S. H. Franchito, and V. B. Rao, 2006: Effects of the Amazonian deforestation on regional climate: A numerical experiment with a coupled biosphere-atmosphere model with soil hydrology. Theor. Appl. Climatol., 85, 1-18.

Sud, Y. C., P. J. Sellers, Y. Mintz, M.-D. Chou, G. K. Walker, and W. E. Smith, 1990: Influence of the biosphere on the global circulation and hydrological cycle-A GCM simulation experiment. Agric. For. Meteor., 52, 133-180.

Varejão-Silva, M. A., S. H. Franchito, and V. B. Rao, 1998: A coupled biosphere-atmosphere climate model suitable for use in climatic studies due to land surface alterations. J. Climate, 11, 1749-1767.

Voldoire, A., 2006: Quantifying the impact of future land-use changes against increases in GHG concentrations. Geophys. Res. Lett., 33, L04701, doi:10.1029/2005GL024354.

Walko, R. L., and Coauthors, 2000: Coupled atmospherebiophysics-hydrology models for envirnmental modeling. J. Appl. Meteor., 39, 931-944.

Zhang, T., 1994: Sensitivity properties of a biosphere model based on BATS and a statistical-dynamical climate model. J. Climate, 7, 891-913. 
Copyright of Journal of Applied Meteorology \& Climatology is the property of American Meteorological Society and its content may not be copied or emailed to multiple sites or posted to a listserv without the copyright holder's express written permission. However, users may print, download, or email articles for individual use. 